\title{
Humanoid Robot Application as COVID-19 Symptoms Checker Using Computer Vision and Multiple Sensors
}

\author{
Muhammad Yeza Baihaqi ${ }^{1 *)}$, Vincent ${ }^{2)}$, and Joni Welman Simatupang ${ }^{3)}$ \\ 1,2,3) Electrical Engineering Study Program, President University, Indonesia \\ Corresponding Email: *) muhammadyezab@gmail.com
}

\begin{abstract}
Novel Corona Virus (nCoV) infects human's respiratory system. It spreads easily when an infected person makes a close contact with other people. To prevent its massive spread, it is necessary to ensure anyone coming to a certain place is not being infected. The symptoms include high body temperature $\left(\geq 37.5^{\circ} \mathrm{C}\right)$ and low oxygen saturation level $(\leq \mathbf{9 5 \%})$. This day, most places only check the human body temperature. Thus, the authors are interested to make an attempt to design a system that is able to measure both human body temperature and oxygen saturation level. This work also applies the 7-DoF Upper-Body of Humanoid Robot to prevent virus spread from and to the employee. The system will detect the coming of visitors by using face detection. It requires 7.24 seconds to detect the visitor without a mask, and 1.26 second when the visitor wears a mask. The body temperature measurement was done using GY-906 temperature sensor with an error of $0.51 \%$. For the oxygen saturation level measurement, MAX30100 pulse oximeter module was applied and showed an error of $0.78 \%$. In addition, the upper-body of humanoid robot will perform some gestures to instruct the visitors in every process of the system. The implemented 7-DoF upper-body of humanoid robot has $93.33 \%$ gesture comprehension rate. In conclusion, the overall system has been tested and showed success rate up to $75 \%$.
\end{abstract}

Keywords: ESP32-CAM, Human Body Temperature, nCoV, Oxygen Saturation Level, 7-DoF upper-body of Humanoid Robot.

\section{INTRODUCTION}

Novel Corona Virus (nCoV) is a type of virus that infects human's respiratory system. The number of patients being treated due to this virus is significant, since the virus can rapidly spread when there is close exposure [1]. To make sure the spreading of this virus is at its slowest rate, the government of Indonesia has taken several measures, and one of them is to implement the physical distancing [2]. Besides, another solution offered is to obligate everyone to obey the health protocols [3].

Another way to suppress the spreading is to check whether a person is being infected or not, especially before they get into a crowded place. To do so, there are one symptom that can be easily detected, which is the human body temperature. Its normal value ranges between $35{ }^{\circ} \mathrm{C}$ and $37{ }^{\circ} \mathrm{C}$ [4]. If one has a higher temperature than this, then there is a possibility of being infected. As the implementation, many places checked the temperature of its visitor at the entrance gate, to make sure all people inside are safe. Most of public places assign the security officer to do manual temperature checking using thermo gun. This is not really safe as the virus can be transmitted to and from the officer.

Several innovations have been made to check COVID19 symptoms. For instance, author in [5] focused on making a system where the result of the sensor read is sent automatically via Bluetooth connection to a PC or smartphone. However, this system is limited to the range of the Bluetooth connection. Author in [6] created a system that sends the data to a smartphone via $\mathrm{Wi}-\mathrm{Fi}$ connection automatically. However, the implementation is not too efficient for mass usage, since the sensor is mounted to the smartphone. Author in [7] made a system that is able to send the result via MQTT protocol automatically. Author in [8] built a system that is able to send the data to Firebase. In this way, the authorized people could access the data from anywhere as long as they have the access to the database. In conclusion, many researches only focus on data collection, and still requires a staff to supervise the visitor to do checking using the system. Emphasis on computer vision as the visitor detector, adding oxygen level sensor, and humanoid robot as officer to create a positive user experience are the new aspects in this research.

In this study, the authors were interested to build a humanoid robot that will substitute the officer. Through the computer vision algorithm, the robot will notice when a new visitor is coming. Then it will check the visitor's body temperature. Considering this parameter is not the only symptom shown by an infected person [9], the robot will also check the visitor's oxygen level. In addition, the normal oxygen saturation level is in between $95 \%$ and $100 \%$ [10]. By having more parameters to be checked, the more precise detection can be achieved, thus providing a safer environment to the other healthy people.

Besides preventing the spread of the virus from and to the officer, robot was also selected carefully because it is suitable for a repetitive task (measuring the visitor's body temperature) [11]. The humanoid robot will also communicate with the visitors by giving any signs as the instructions on what ones must do. For example, it might ask the guest to come closer because the sensor cannot 
read the body temperature. In addition, the robot will also give some sign languages either to let the visitor in or to reject him.

The rest of this paper is organized as follows. Section II focuses on discussion of the flowchart and wiring diagram used to finish this project. Next, Section III presents and discusses the result. Finally, Section IV concludes this work.

Table 1. Comparison with Past Researches

\begin{tabular}{cccc}
\hline No & Authors & Function & $\begin{array}{c}\text { Data } \\
\text { Transfer }\end{array}$ \\
\hline 1 & R. Wulandari [5] & $\begin{array}{c}\text { Temperature } \\
\text { Checking }\end{array}$ & Bluetooth \\
\hline 2 & $\begin{array}{c}\text { B. A. Setyawan } \\
\text { et.al. [6] }\end{array}$ & $\begin{array}{c}\text { Temperature } \\
\text { Checking }\end{array}$ & Wi-Fi \\
\hline 3 & $\begin{array}{c}\text { D. I. Saputra } \\
\text { et. al. [7] }\end{array}$ & $\begin{array}{c}\text { Temperature } \\
\text { Checking }\end{array}$ & $\begin{array}{c}\text { Wi-Fi } \\
\text { (MQTT) }\end{array}$ \\
\hline 4 & $\begin{array}{c}\text { I. Gunawan et. } \\
\text { al. [8] }\end{array}$ & $\begin{array}{c}\text { Temperature } \\
\text { Checking }\end{array}$ & $\begin{array}{c}\text { Wi-Fi } \\
\text { (Firebase) }\end{array}$ \\
\hline 5 & This Work & $\begin{array}{c}\text { Temperature and } \\
\text { Oxygen Saturation } \\
\text { Level Checking }\end{array}$ & Wi-Fi \\
\hline
\end{tabular}

\section{Methodology}

This section starts with an explanation on several key success factors for the system. It covers the discussion on the upper-body of humanoid robot, followed by the elaboration on its movements. Then, ESP32-CAM and the UART communication are explained. Several sensors accompanying this robot, i.e., GY-906 temperature sensor and MAX30100 pulse oximeter, are then discussed. Finally, the section discusses the flowchart and the wiring diagram of the system.

\section{A. Upper-Body of Humanoid Robot}

One of the earliest mentions of the term 'Robot' was made by Karel Capek. In his play, he introduced it to describe a servant that looks like a human being [12]. The idea is to create an object which can mimic the human's tasks [13]. Various researches have been done on the second half of twentieth century [14], [15]. A robot can be segmented into two main parts, one that resembles human's 7-DoF upper-body, and another one resembling the lower part.

The 7-DoF upper-body of humanoid robot resembles a whole human body without legs. It comes with different sizes, starting from the small one, human-alike size, to an even bigger size, depending on the designated functionality. This robot is made of servos to make movement as detailed as possible. For instance, the elbow can be represented by one servo which moves in one direction. To accommodate the other directions, another servo can be installed and programmed. By installing several servos, the robot is able to make a movement resembling what a human can do. Those movements can be controlled in some ways, such as by using Bluetooth connection [16].
The humanoid robot can perform various functions, including greeting, accompanying, and providing information. It is phenomenal as it provides people with a brand-new user experience. This robot will be required to perform monotonous duties, allowing workers to focus on more important tasks [17]. Being greeted by a humanoid robot is a new experience for visitors. Since 2016, humanoid robots have been used in the hotel industry in several countries, such as in China, Japan, and Malaysia [18]-[20].

Body language is classified as a paralanguage, which refers to any type of communication that does not rely on the spoken word. Sign language is also included in this category and it has a number of advantages. Intercultural communication is defined as communication between two or more people with significant cultural differences, including linguistic diversity [21], which has a crucial role in cross-cultural communication [22]. Sign language is a standardized language using signs and signals to communicate with the disabled [23]. Thus, a nonverbal message can replace a verbal message. It can be easily understood without any spoken information by simply making a certain gesture [24]. Therefore, it is as old as mankind and a powerful tool of communication.

Due to the importance of sign language, the authors focused in implementing upper-body of humanoid robot to perform several gestures using its hands and head to mimic a sign language. This robot is equipped with 7-DoF to assist its mission. Figure 1 shows the 7-DoF upperbody of humanoid robot used in this work.

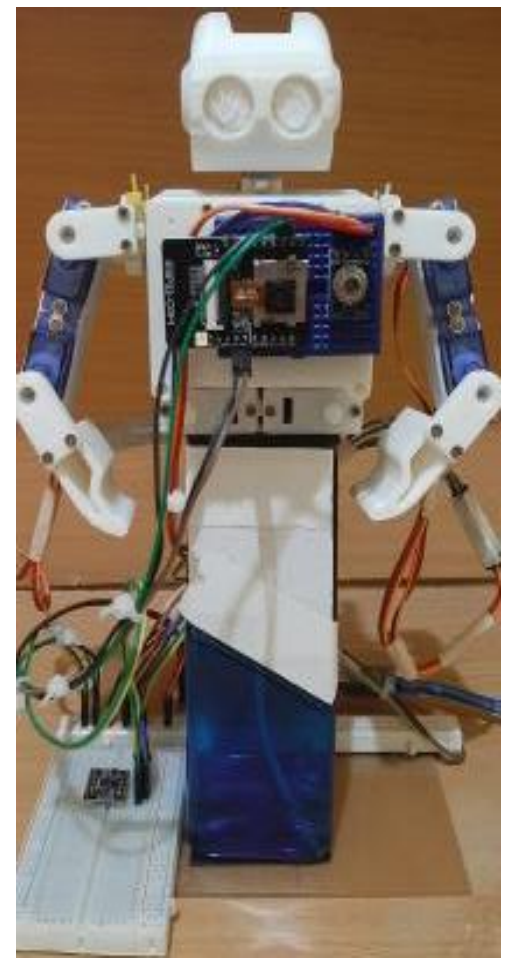

Figure 1. 7-DoF upper-body of Humanoid Robot

\section{B. Humanoid Robot Gestures}

The 7-DoF upper-body of humanoid robot has six possible movements to be performed. Figure 2 depicts the 
situation of the first movement, where the robot moves both of its hands to let the visitor know the location of the temperature sensor. In this case, the robot is asking the visitor to measure the body temperature. If the measurement is unsuccessful, the robot will make another movement to ask the visitor to come closer and remeasure. It is labelled as movement 2 as shown in Figure 3 . When the measurement is successful, the robot will then ask the visitor to measure the oxygen saturation level. Its hand movement will inform the visitor where the pulse oximeter module is. This gesture is mentioned as movement 3 as indicated in Figure 4. If the measurement was unsuccessful, the robot will then move its hands again above the pulse oximeter module to let the visitor remeasure. This movement is depicted in Figure 5, and called as movement 4 . After successfully measuring the parameters, the robot will welcome the visitor to enter the site by showing the direction to the entrance. This movement is shown in Figure 6, and labelled as movement 6 . Finally, the robot will raise both hands and shake its head to reject the visitor if one parameter (or more) does not meet the threshold. This movement is pictured in Figure 7, and named as movement 6.

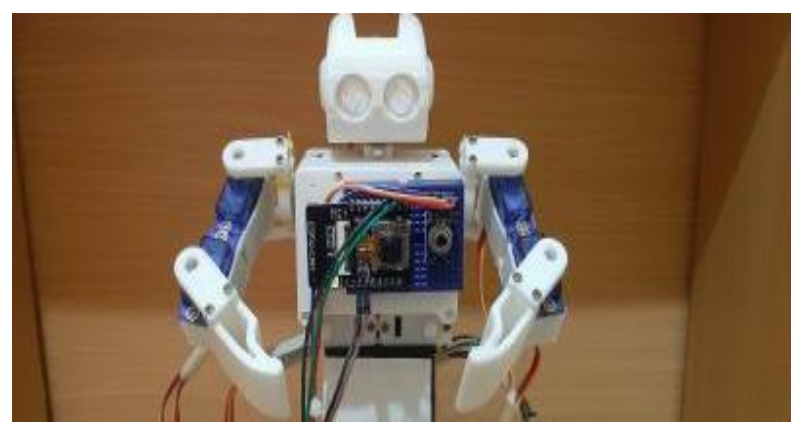

Figure 2. 7-DoF upper-body of humanoid robot's gesture asking the visitor to measure body temperature (movement 1 )

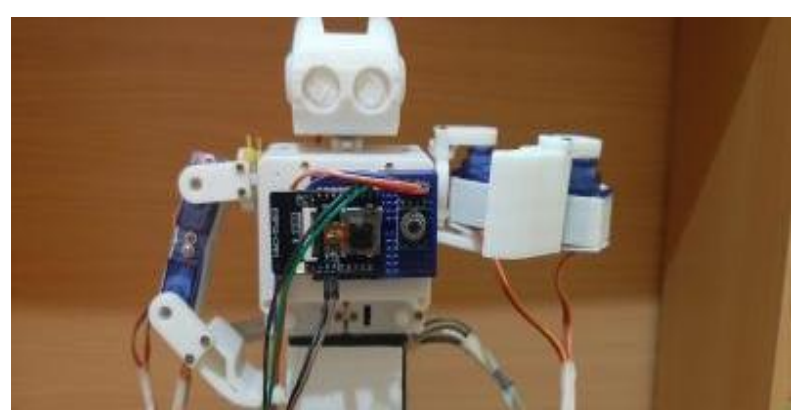

Figure 3. 7-DoF upper-body of humanoid robot's gesture asking the visitor to re-measure body temperature (movement 2)

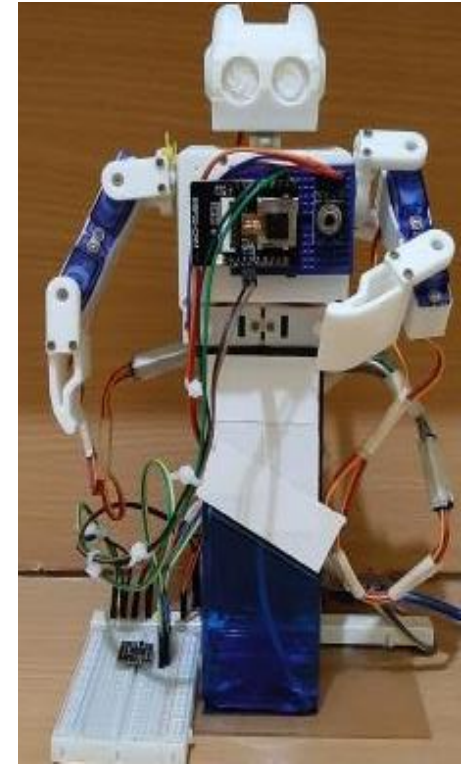

Figure 4. 7-DoF upper-body of humanoid robot's gesture asking the visitor to measure oxygen saturation level (movement 3)

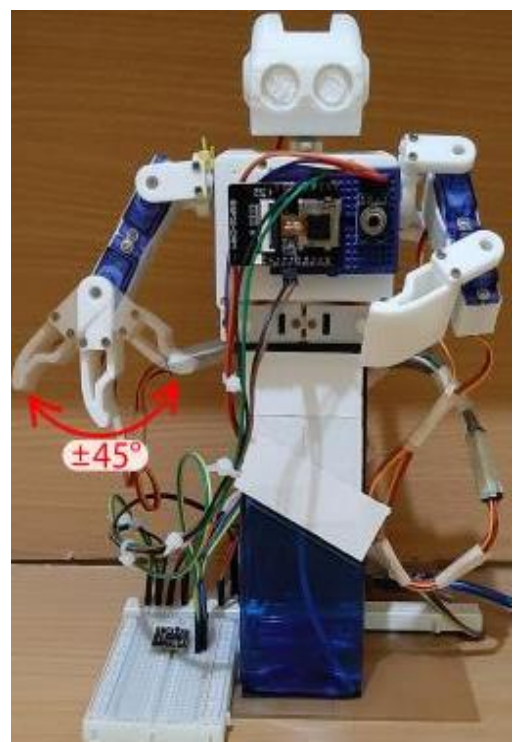

Figure 5. 7-DoF upper-body of humanoid robot's gesture asking visitor to re-measure oxygen saturation level (movement 4)

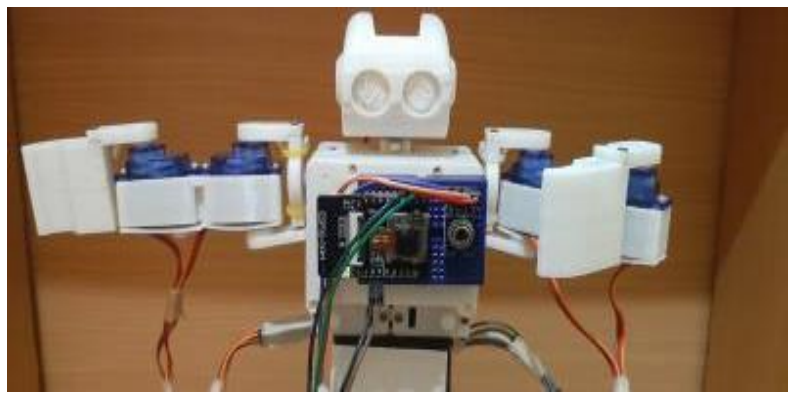

Figure 6. 7-DoF upper-body of humanoid robot's gesture allowing visitor to enter the area (movement 5) 


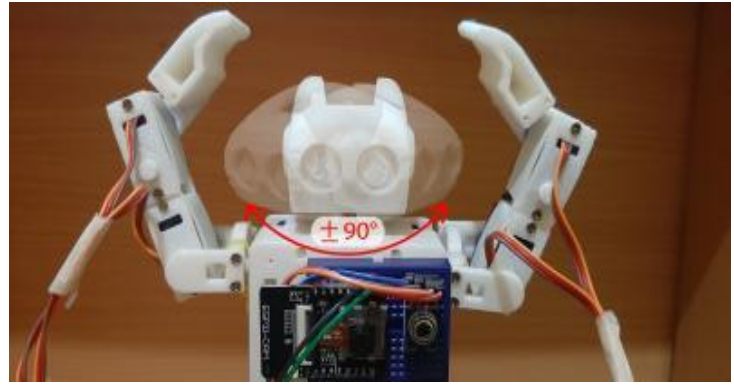

Figure 7. 7-DoF upper-body of humanoid robot's gesture rejecting visitor to enter the area (movement 6)

\section{ESP32-CAM}

ESP32-CAM is a module of ESP32-S chip empowered with a tiny camera, whose vision covers $10 \mathrm{~cm}-60 \mathrm{~cm}$. A normal ESP32 has several GPIO ports to establish connection with sensors or actuators, while this module has an additional feature of microSD card slot to store images taken by its camera or files for further processes. This module does not embed with a USB connector, thus FTDI programmer is required to upload the code through serial pins of UOR and UOT [25]. Figure 8 shows the ESP32-CAM module.

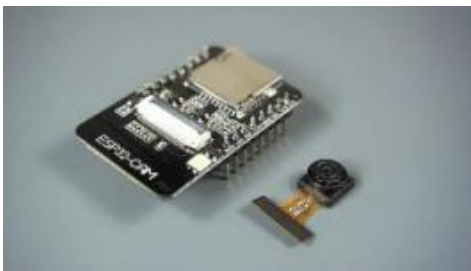

Figure 8. ESP32-CAM Module [25]

\section{UART Communication}

Universal Asynchronous Receiver/Transmitter, also known as UART, is a serial communication between two devices, and it is meant only for two devices communication scheme. Figure 9 shows the UART connection schematic in a simple form. As implied, the transmitter part of a device, denoted as Tx, is connected to another device's receiver part, denoted as $\mathrm{Rx}$, and vice versa.

In Arduino UNO, pin 1 and 0 in digital section are meant for the Tx and Rx of this communication type, respectively. In general, the data to be sent is divided into packets with start bit, data bits, parity bit, and the stop bits [26].

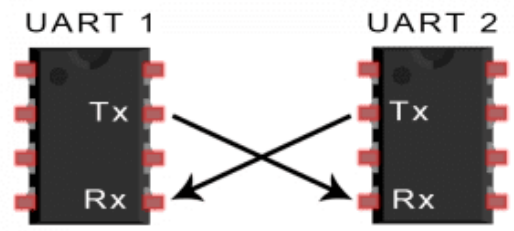

Figure 9. UART Communication Schematic [26]

\section{E. GY-906 Temperature Sensor}

GY-906 is an infrared temperature sensor. This sensor is able to take measurement in between $-70{ }^{\circ} \mathrm{C}$ and 383 ${ }^{\circ} \mathrm{C}$, with the accuracy of $0.02{ }^{\circ} \mathrm{C}$ at field of view of $80^{\circ}$.
Since it is a contactless sensor, it is advised to have a distance of $5 \mathrm{~cm}$ to $10 \mathrm{~cm}$ between the sensor and the object to have a good measurement. Its basic working principle is to measure the infrared level radiated by the object according to Stefan-Boltzmann law [27]. Figure 10 shows the GY-906 temperature sensor.

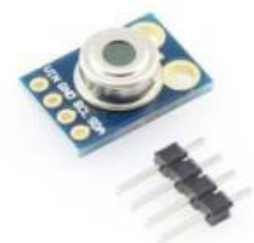

Figure 10. GY-906 Temperature Sensor [27]

\section{F. MAX30100 Pulse Oximeter}

MAX30100 is a sensor to measure pulse oximetry and heart-rate which operates with a voltage ranging from 1.8 $\mathrm{V}$ to $5.5 \mathrm{~V}$. The basic concept of its working principle is based on the fact that oxygenated blood is able to absorb more infrared light. Thus, it is possible to measure the oxygen saturation level. Additionally, by measuring the delay between the increment and decrement of oxygenated blook due to blood pumping, this sensor is able to measure the pulse rate [28]. Figure 11 shows the MAX30100 pulse oximeter module.

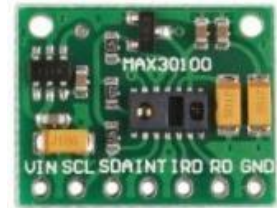

Figure 11. MAX30100 Pulse Oximeter Module [28]

\section{G. Flowchart}

The flowchart of this work is presented in Figure 12.

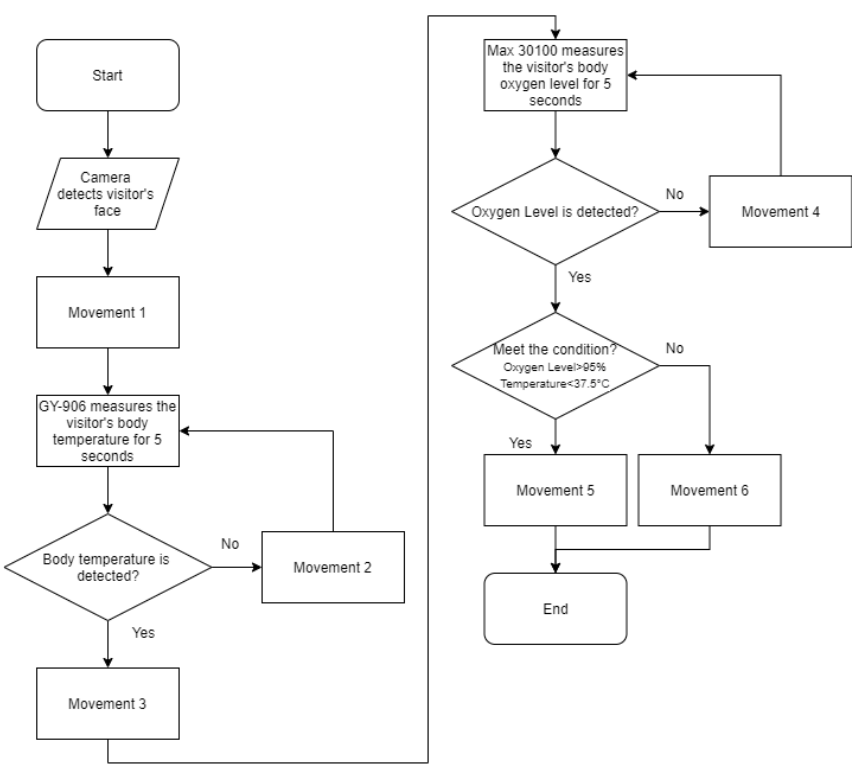

Figure 12. Flowchart to detect temperature, oxygen saturation level, and to allow or reject visitor 
The system starts after a visitor is detected inside ESP32-CAM coverage area. After being successfully detected, it will lead the 7-DoF upper-body of humanoid robot to perform movement 1 , asking the visitor to get closer to the GY-906 sensor to reach its ideal detection distance. After the visitor is close enough to the GY-906, the body temperature measurement is started. If the reading is unsuccessful, the robot will perform movement 2 , asking the visitor to re-measure body temperature. Otherwise, it will make movement 3 , asking the visitor to place his finger above MAX30100 sensor for oxygen level measurement. This measurement will take approximately 5 seconds, and if the reading is unsuccessful, the robot will perform movement 4 to ask the visitor to re-measure the oxygen saturation. When the reading has been successfully made, the robot will perform movement 5 , allowing the visitor to come in if the temperature is below $37.5^{\circ} \mathrm{C}$ and oxygen saturation level is higher than $95 \%$. Otherwise, it will perform movement 6 , indicating rejection to the visitor.

\section{H. Block Diagram}

All the sensors, MAX30100 and GY-906 are connected to ESP32-CAM Module where the humanoid robot is actuated by using five servos and controlled by using Arduino UNO. In this research, ESP32-CAM will communicate with 7-DoF upper-body of humanoid robot through UART communication. The detail block diagram is shown in Figure 13.

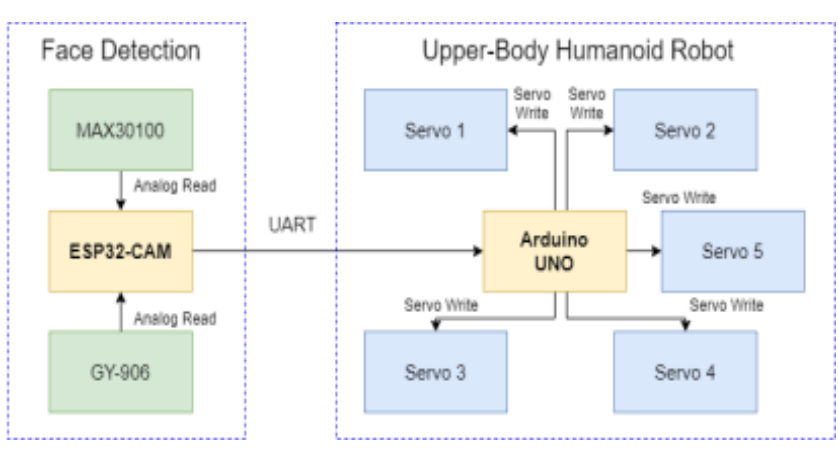

Figure 13. Block Diagram

\section{RESUlTS AND DisCUSSION}

This chapter focuses in presenting and discussing the result achieved from the implementation of the flowchart and the block diagram elaborated in the previous section.

There are two main analyses in this section. The first one emphasizes on the gesture of the 7-DoF upper-body of humanoid robot, and the second one highlights the performance of the ESP32-CAM, GY-906 temperature sensor, as well as the MAX30100 pulse oximeter module. Finally, the success rate of the system is also evaluated by the end of the section.

\section{A. Gesture Analysis}

Table 2 summarizes the responses from ten respondents for each possible movement by the 7-DoF upper-body of humanoid robot. Each respondent had never met this robot before, thus making them unfamiliar with the movements it could perform.

Table 2. Responses to All Gestures

\begin{tabular}{ccccccc}
\hline \multirow{6}{*}{$\begin{array}{c}\text { Respondent } \\
\text { No. }\end{array}$} & 1 & 2 & 3 & 4 & 5 & 6 \\
\cline { 2 - 7 } 1 & $\checkmark$ & $\checkmark$ & $\checkmark$ & $\checkmark$ & $\checkmark$ & $\checkmark$ \\
\hline 2 & X & $\checkmark$ & $X$ & $\checkmark$ & $\checkmark$ & $\checkmark$ \\
\hline 3 & $\checkmark$ & $\checkmark$ & $\checkmark$ & $\checkmark$ & $\checkmark$ & $\checkmark$ \\
\hline 4 & $\checkmark$ & $\checkmark$ & $\checkmark$ & $\checkmark$ & $\checkmark$ & $\checkmark$ \\
\hline 5 & $\checkmark$ & $\checkmark$ & $\checkmark$ & $\checkmark$ & $\checkmark$ & $\checkmark$ \\
\hline 6 & $\checkmark$ & $\checkmark$ & $\checkmark$ & $\checkmark$ & $\checkmark$ & $\checkmark$ \\
\hline 7 & $\checkmark$ & $\checkmark$ & $X$ & $\checkmark$ & $\checkmark$ & $\checkmark$ \\
\hline 8 & $\checkmark$ & $\checkmark$ & $\checkmark$ & $\checkmark$ & $\checkmark$ & $\checkmark$ \\
\hline 9 & $\checkmark$ & $\checkmark$ & $\checkmark$ & $\checkmark$ & $\checkmark$ & $\checkmark$ \\
\hline 10 & $X$ & $\checkmark$ & $\checkmark$ & $\checkmark$ & $\checkmark$ & $\checkmark$ \\
\hline & & & & & &
\end{tabular}

Movement 2, 4, 5, and 6 were perfectly recognized by all respondents. Thus, the gesture comprehension rate is $100 \%$ for these four movements. On the other hand, movement 1 and 3 seems to be harder to understand. Thus, the gesture comprehension rate for these two movements is $80 \%$.

The respondents gave some feedback for the movement. The first movement looked like a welcoming gesture, so it might confuse the first-time visitor as ones did not know about the existence of a temperature sensor on the body of the robot. For the third movement, the feedback was about the location of the pulse oximeter module. As shown in Figure 4, the sensor is located quite far from the body of the robot. It was suggested to have it closer, so the gesture can be understood easier.

Overall, the gesture comprehension rate for all of the movements for the 7-DoF upper-body of humanoid robot is $93.33 \%$.

\section{B. Performance Analysis}

The face detection process is done by using the camera in the ESP32-CAM. There are two cases in this section. The first one is when the visitor did not wear a mask, while the second one is when the visitor wore a mask. Figure 14 and Figure 15 shows the condition of the visitor without and with a mask, respectively. Similarly, Figure 16 and Figure 17 shows the condition of the visitor wearing eyeglasses without and with a mask, respectively. The one without eyeglasses is called as visitor 1 , while the other one is visitor 2 . 


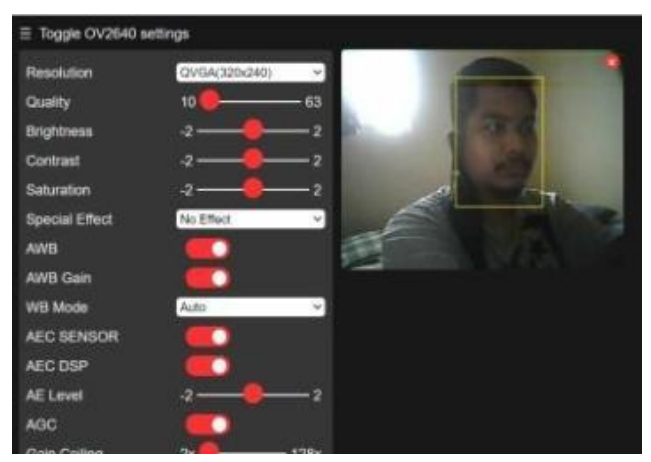

Figure 14. Face detection when visitor 1 is not wearing a mask

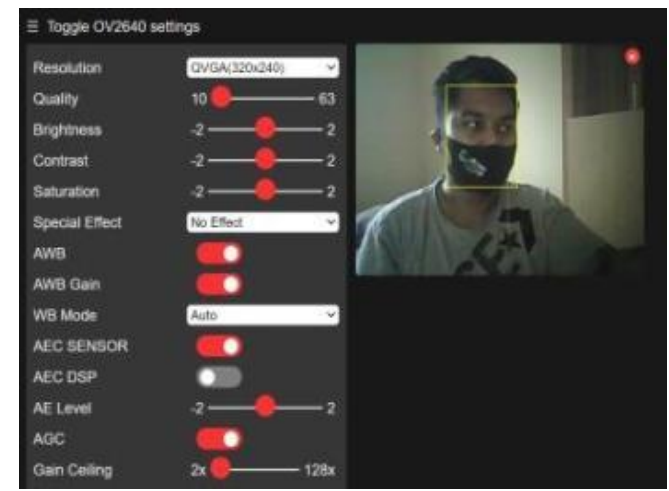

Figure 15. Face detection when visitor 1 is wearing a mask

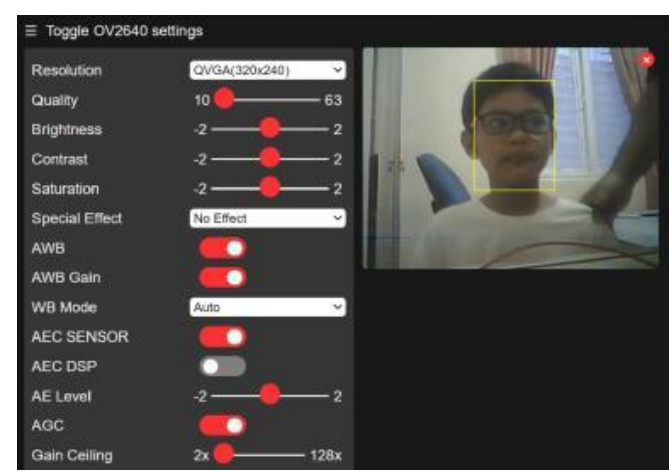

Figure 16. Face detection when visitor 2 is not wearing a mask

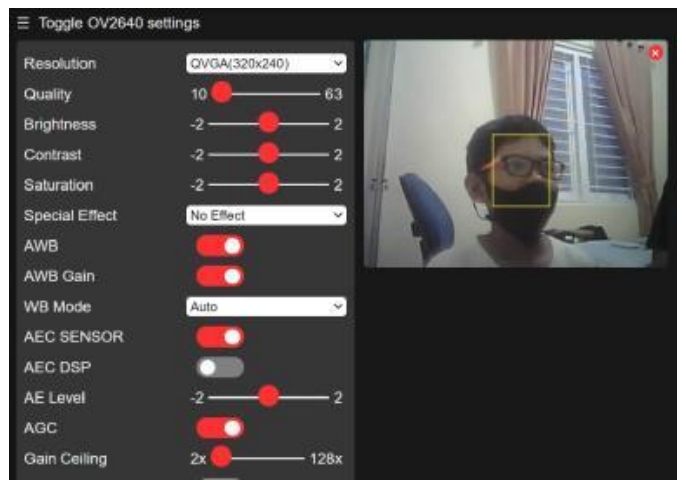

Figure 17. Face detection when visitor 2 is wearing a mask

Comparing both respondents, it took 5.90 seconds on average to detect the first respondent, while it took 8.97 seconds for the second one. It is clear that the system takes longer time to detect visitor with glasses.

The average for the twenty attempts of detecting a visitor's face with a mask was 7.24 seconds, while a visitor without a mask took 1.26 seconds to be detected on average. Additionally, there were four out of twenty attempts when the face was not detected by the system, making the face detection for a visitor with mask to have a success rate of $80 \%$. Note that the three failed attempts came from the visitor with glasses.

Next, the temperature sensor was evaluated by comparing the result with commercial thermo gun. Table 3 shows the result of thermometer measurement using GY-906 temperature sensor and the thermo gun over sixteen attempts.

Table 3 actually recorded twenty attempts. However, since the face detection part of the system encountered error on the sixth, eleventh, fourteenth, and sixteenth attempts, the sensors did not make any measurement. Thus, the table recorded nothing for GY-906 temperature sensor. Therefore, there were only sixteen readings. The same thing goes for MAX30100 pulse oximeter module.

The highest difference is shown on the thirteenth attempt at $1.11 \%$ with a measurement difference by 0.4 ${ }^{\circ} \mathrm{C}$. While the lowest difference is shown at $0.00 \%$, which is equivalent to no difference. On average, the difference between the two devices is $0.51 \%$.

Table 3. Time to Detect Face of Visitor

\begin{tabular}{|c|c|c|c|}
\hline No & $\begin{array}{l}\text { Respondent } \\
\text { No. }\end{array}$ & $\begin{array}{l}\text { With Mask } \\
\text { (second) }\end{array}$ & $\begin{array}{c}\text { Without Mask } \\
\text { (second) }\end{array}$ \\
\hline 1 & 1 & 9.88 & 1.00 \\
\hline 2 & 1 & 5.02 & 0.50 \\
\hline 3 & 1 & 7.01 & 2.00 \\
\hline 4 & 1 & 7.60 & 2.55 \\
\hline 5 & 1 & 4.00 & 1.88 \\
\hline 6 & 1 & $\begin{array}{l}\text { Not detected / } \\
\text { more than } 10 \\
\text { seconds }\end{array}$ & 0.56 \\
\hline 7 & 1 & 5.00 & 0.50 \\
\hline 8 & 1 & 4.80 & 1.00 \\
\hline 9 & 1 & 6.05 & 1.36 \\
\hline 10 & 1 & 3.76 & 1.34 \\
\hline 11 & 2 & $\begin{array}{l}\text { Not detected / } \\
\text { more than } 10 \\
\text { seconds }\end{array}$ & 0.56 \\
\hline 12 & 2 & 9.00 & 1.05 \\
\hline 13 & 2 & 8.10 & 1.20 \\
\hline 14 & 2 & $\begin{array}{l}\text { Not detected / } \\
\text { more than } 10 \\
\text { seconds }\end{array}$ & 2.01 \\
\hline 15 & 2 & 8.20 & 1.00 \\
\hline 16 & 2 & $\begin{array}{l}\text { Not detected / } \\
\text { more than } 10 \\
\text { seconds }\end{array}$ & 0.56 \\
\hline 17 & 2 & 10.00 & 1.98 \\
\hline 18 & 2 & 11.00 & 1.00 \\
\hline 19 & 2 & 8.88 & 2.03 \\
\hline 20 & 2 & 7.60 & 1.10 \\
\hline
\end{tabular}


As for the MAX30100 pulse oximeter module, the highest difference is shown at $2.08 \%$ with a measurement difference by $2 \%$ of oxygen saturation level, while the lowest difference is shown at $0.00 \%$, implying no difference detected. On average, the difference between the two measurement devices is $0.78 \%$.

Finally, the success rate of the system is analyzed in this section. As mentioned in the previous part, the 7-DoF upper-body of humanoid robot will make a welcoming gesture and allow the visitor to come in only when the visitor's body temperature is lower than $37.5{ }^{\circ} \mathrm{C}$ and oxygen saturation level at least 95\%. The "Expected
Result" shown in Table 4 is taken by considering the measurement from commercial thermo gun and commercial pulse oximeter, then comparing them with the threshold set in the beginning. The "Actual Result ", on the other hand, is the real movement made by the 7-DoF upper-body of humanoid robot as the response to the measurement made by GY-906 temperature sensor and MAX30100 pulse oximeter module.

There were two out of ten attempts where the system did not show the same results as it should be, i.e., on the fifth and sixth attempt.

Table 4. Comparison between Expected and Actual Results

\begin{tabular}{|c|c|c|c|c|c|c|c|c|}
\hline No & $\begin{array}{l}\text { Respondent } \\
\text { No. }\end{array}$ & $\begin{array}{l}\text { Time to Detect } \\
\text { (second) }\end{array}$ & $\begin{array}{c}\text { GY-906 } \\
\left({ }^{\circ} \mathrm{C}\right)\end{array}$ & $\begin{array}{c}\text { Commercial } \\
\text { Thermo gun } \\
\left({ }^{\circ} \mathrm{C}\right)\end{array}$ & $\begin{array}{l}\text { MAX30100 } \\
\text { (second) }\end{array}$ & $\begin{array}{c}\text { Commercial } \\
\text { Pulse Oximeter } \\
(\%)\end{array}$ & $\begin{array}{l}\text { Expected } \\
\text { Result }\end{array}$ & Actual Result \\
\hline 1 & 1 & 9.88 & 36.20 & 36.40 & 95 & 96 & Allowed & Allowed \\
\hline 2 & 1 & 5.02 & 35.50 & 35.50 & 96 & 95 & Allowed & Allowed \\
\hline 3 & 1 & 7.01 & 36.80 & 37.00 & 97 & 97 & Allowed & Allowed \\
\hline 4 & 1 & 7.60 & 36.60 & 36.40 & 98 & 98 & Allowed & Allowed \\
\hline 5 & 1 & 4.00 & 37.00 & 37.20 & 94 & 95 & Allowed & Not Allowed \\
\hline 6 & 1 & Not detected & - & 35.80 & - & 97 & Allowed & No Response \\
\hline 7 & 1 & 5.00 & 35.00 & 35.20 & 98 & 98 & Allowed & Allowed \\
\hline 8 & 1 & 4.80 & 37.40 & 37.30 & 97 & 96 & Allowed & Allowed \\
\hline 9 & 1 & 6.05 & 37.60 & 37.80 & 98 & 96 & $\begin{array}{c}\text { Not } \\
\text { Allowed }\end{array}$ & Not Allowed \\
\hline 10 & 1 & 3.76 & 36.80 & 37.00 & 97 & 96 & Allowed & Allowed \\
\hline 11 & 2 & Not detected & - & 37.10 & - & 97 & Allowed & No Response \\
\hline 12 & 2 & 9.00 & 35.20 & 35.30 & 98 & 98 & Allowed & Allowed \\
\hline 13 & 2 & 8.10 & 35.60 & 36.00 & 99 & 97 & Allowed & Allowed \\
\hline 14 & 2 & Not detected & - & 38.30 & - & 96 & $\begin{array}{c}\text { Not } \\
\text { Allowed }\end{array}$ & No Response \\
\hline 15 & 2 & 8.20 & 35.01 & 35.40 & 97 & 97 & Allowed & Allowed \\
\hline 16 & 2 & Not detected & - & 38.00 & - & 94 & $\begin{array}{c}\text { Not } \\
\text { Allowed }\end{array}$ & No Response \\
\hline 17 & 2 & 10.00 & 36.80 & 37.00 & 97 & 96 & Allowed & Allowed \\
\hline 18 & 2 & 11.00 & 37.60 & 37.90 & 95 & 96 & $\begin{array}{c}\text { Not } \\
\text { Allowed }\end{array}$ & Not Allowed \\
\hline 19 & 2 & 8.88 & 35.60 & 35.60 & 98 & 98 & Allowed & Allowed \\
\hline 20 & 2 & 7.60 & 35.90 & 36.00 & 99 & 98 & Allowed & Allowed \\
\hline
\end{tabular}

On the fifth attempt, the system denied the access for the visitor due to low oxygen saturation level which was only $94 \%$ where the minimum level should be $95 \%$. However, the commercial pulse oximeter showed the reading of $95 \%$, which allowed the visitor to come in. Thus, the system made wrong output due to the error from the pulse oximeter module, even though the temperature sensor showed no problem.

There were four attempts where the system did not perform any movement. This condition is noted as "No Response". It occurred when the system took more than ten seconds to detect a visitor's face. In this case, the system is considered failed.

At the same time, there was once where the system rejected a visitor while it should not do so. Even though the GY-906 temperature sensor's measurement was below the threshold, the MAX30100 pulse oximeter module read $94 \%$. As a reference, the commercial one showed $95 \%$ (minimum value for a visitor to be allowed to come in), thus causing the system to reject the visitor, although it should give the permission to enter.

Overall, there were 5 out of 20 attempts where the system failed to provide correct responses. Thus, making the system to have a success rate of $75 \%$.

\section{CONCLUSION}

In conclusion, this work has successfully designed a system to check a visitor's body temperature and oxygen saturation level with a 7-DoF upper-body of humanoid robot. It could perform six movements to communicate with the visitors, and the gesture comprehension rate is $93.33 \%$. The face detection system took 7.24 seconds to detect the visitor without a mask, and 1.26 seconds to 
detect the visitor with a mask. For the sensors, GY-906 temperature sensor has an error of $0.51 \%$ and MAX30100 pulse oximeter sensor has $0.78 \%$ error. The overall system has a success rate up to $75 \%$. For future improvement, the computer vision algorithm can be improved as well as the humanoid robot's DoF. It is also possible to apply database and make a front-end user interface.

\section{REFERENCES}

[1] D. Telaumbanua, "Urgensi Pembentukan Aturan Terkait Pencegahan Covid-19 di Indonesia," QALAMUNA J. Pendidikan, Sos. dan Agama, vol. 12, no. 01, pp. 59-70, 2020, doi: 10.37680/qalamuna.v12i01.290.

[2] N. Nurhalimah, "Upaya Bela Negara Melalui Sosial Distancing dan Lockdown Untuk Mengatasi Wabah COVID-19," SSRN Electron. J., vol. 19, 2020, doi: $10.2139 / \mathrm{ssrn} .3576405$.

[3] H. N. Ulya, "Alternatif Strategi Penanganan Dampak Ekonomi Covid-19 Pemerintah Daerah Jawa Timur Pada Kawasan Agropolitan," El-Barka J. Islam. Econ. Bus., vol. 3 , no. 1, pp. 80-109, 2020, doi: 10.21154/elbarka.v3i1.2018.

[4] UGM, "Kenali Happy Hypoxia Syndrome." https://ugm.ac.id/id/berita/19992-kenali-happy-hypoxiasyndrome-gejala-baru-covid-19 (accessed Jan. 31, 2021).

[5] R. Wulandari, "Rancang Bangun Pengukur Suhu Tubuh Berbasis Arduino Sebagai Alat Deteksi Awal Covid-19," Pros. SNFA (Seminar Nas. Fis. dan Apl., vol. 5, pp. 183189, 2020, doi: 10.20961/prosidingsnfa.v5i0.46610.

[6] B. A. Setyawan, T. Agustianto, S. Fathudin, and A. Widodo, "Prometer: Termometer Non-Kontak Praktis Berbasis," Din. Vokasional Tek. Mesin, vol. 5, no. Azanella, pp. 129-135, 2020.

[7] D. I. Saputra, G. M. Karmel, and Y. B. Zainal, "Perancangan dan Implementasi Rapid Temperature Screening Contactless dan Jumlah Orang Berbasis IOT dengan Protokol MQTT," J. Energy Electr. Eng., vol. 02, no. 01, pp. 20-30, 2020.

[8] I. Gunawan, A. Sudianto, and M. Sadali, "Alat Pengukur Suhu Tubuh Berbasis Internet of Things (IoT) Menggunakan ESP8266 dan Firebase Measuring Body Temperature Based Internet of Things (IoT) Using Esp8266 and Firebase," vol. 11, no. 1, pp. 91-100, 2021.

[9] UI, "Kena Hipoksia kok Pasien COVID-19 Bisa Tak Merasa Sesak." https://fk.ui.ac.id/infosehat/kena-hipoksiakok-pasien-covid-19-bisa-tak-merasa-sesak/ (accessed Feb. 04, 2021).

[10] A. V. Nugroho, "Sistem Monitoring Pasien Robot Covid dengan Parameter Suhu, Detak Jantung, Dan Saturasi Oksigen Berbasis Website," 2020.

[11] "Humanoid Robot Reinvent Customer Experience." https://gfi.world/tn-en/news/parole_expert/139-howhumanoid-robotics-re-invents-customer-experience (accessed Aug. 07, 2021).

[12] S. Behnke, "Humanoid Robots - From Fiction to Reality ?," KI-Zeitschrift, vol. 4, no. December, pp. 5-9, 2008, [Online]. Available: http://www.ais.unibonn.de/papers/KI08_Behnke.pdf.

[13] J. Denny, M. Elyas, S. A. Dcosta, and R. D. DSouza, "Humanoid Robots - Past, Present and the Future," Eur. J. Adv. Eng. Technol., vol. 3, no. 5, pp. 8-15, 2016, [Online]. Available: https://www.researchgate.net/publication/303806185.

[14] S. Schaal, "Historical Perspective of Humanoid Robot Resaerch in the Americas," Humanoid Robot. A Ref., no. October, 2018, doi: 10.1007/978-94-007-7194-9.

[15] A. Takanishi, "Historical Perspective of Humanoid Robot Research in Asia," Humanoid Robot. A Ref., pp. 1-18, 2018, doi: 10.1007/978-94-007-7194-9_145-1.

[16] M. Y. Baihaqi and J. W. Simatupang, "Aplikasi Metode Kontrol Bluetooth Pada Robot Humanoid Berbasis Arduino Mega 2560," Prosiding Seminar Nasional Energi \& Teknologi (SINERGI), vol. 88, pp. 49-56, 2016.

[17] "What is Humanoid Robot." https://gfi.world/tnen/news/parole_expert/139-how-humanoid-robotics-reinvents-customer-experience (accessed Jul. 01, 2021).

[18] D. T, "Humanoid Robot Service Malaysia," 2019. https://www.thesundaily.my/local/ecoworld-to-unveilmalaysias-first-robothotel-YF546100 (accessed Jul. 01, 2021).

[19] T. Verge, "Humanoid Robot Service Japan," 2019. https://www.theverge.com/2019/1/15/18184198/japansrobot-hotel-lay-off-work-forhumans (accessed Jul. 01, 2021).

[20] E. Wang, "Humanoid Robot Service China," 2019. https://www.chinamoneynetwork.com/2018/09/20/alibab asai-unit-to-launch-hospitality-robots-in-october (accessed Jul. 01, 2021).

[21] M. W. Lustig and J. Koester, Intercultural Competence: Intercultural Communication Across Cultures, 6th ed. Boston, 2010.

[22] “Body Language." https://www.alumniportaldeutschland.org/en/career/body-language-interculturalcommunication/ (accessed Jul. 01, 2021).

[23] A. Mindess, Reading Between the Signs: Intercultural Communication for Sign Language Interpreters, 2nd ed. Boston: Intercultural Press.

[24] Klopf and W. Donald, Intercultural Encounters: The Fundamental of Intercultural Communication, 1 st ed. USA: Morton Publishing Company, 1987.

[25] “ESP 32 CAM." https://randomnerdtutorials.com/esp32cam-video-streaming-face-recognition-arduino-ide/ (accessed Feb. 14, 2021).

[26] "UART Communication." https://www.circuitbasics.com/how-to-set-up-uartcommunication-for-arduino/ (accessed Feb. 14, 2021).

[27] “GY906 Temperature Sensor." https: //create.arduino.cc/projecthub/hardyedela/diy-arduinogy-906-infrared-thermometer-5881aa (accessed Feb. 15, 2021).

[28] “MAX30100 Pulse Oximeter." http: //www.alselectro.com/max30100-pulse-oximeter-spo2and-heart-rate-sensor-module.html (accessed Feb. 15, 2021). 